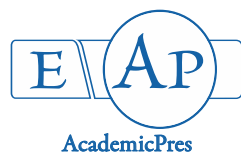

\title{
Vegetation Dynamics and Species Diversity in a Saharan Oasis, Egypt
}

\author{
Fawzy SALAMA ${ }^{1 *}$, Monier ABD EL-GHANI ${ }^{2}$, Ahmed AMRO ${ }^{1}$, \\ Ali GAAFAR ${ }^{3}$, Ayat ABD EL GALIL ${ }^{3}$ \\ ${ }^{1}$ Assiut University, Faculty Sciences, Department of Botany and Microbiology, Assiut, \\ Egypt; fawzysalama2020@yahoo.com (*corresponding author); ahmed.amro81@yahoo.com \\ ${ }^{2}$ Cairo University, Faculty of Science, Department of Botany and Microbiology, Giza 12613,Egypt; moniermohamedabdelghani@gmail.com \\ ${ }^{3}$ Assiut University, Faculty of Sciences, New Valley branch, Department of Botany, Assiut, \\ Egypt; aligaafar2006@yahoo.com; ayatabdelmonembotany@gmail.com
}

\begin{abstract}
The present study provides an analysis of the floristic composition, habitat types, vegetation structure and species diversity, elucidating the role of the environmental factors that affect species distribution in Kharga Oasis, Western Desert, Egypt. The vegetation was sampled from 89 permanently visited stands in 12 sites situated along N - S line transect across the oasis, and extending for about $185 \mathrm{~km}$ to cover as much as possible the physiognomic variation in habitats. Four main habitats were recognized and forming concentric zones (from inside to outside): farmlands and date-palm orchards represent the inner zone, the waste-salinized lands (not saltmarshes) in the middle zone, and the surrounding (bounding) desert in the outer zone. A total of 122 species from 35 families and 102 genera represented the flora of the study area. Poaceae, Asteraceae and Fabaceae were the major families, which constituted $47 \%$ of the total flora. Classification using Bray-Curtis cluster analysis produced 4 vegetation groups (A - D); each can be linked to a certain habitat. The arrangement of habitat zones along the first DCA axis can be noticed: outer zone (bounding desert), middle zone (waste-salinized lands) and inner zone (arable lands). On the other hand, farmlands and date-palm orchard groups were separated from each other along the second DCA axis. The relationship between the vegetation and soil variables was studied using Canonical Correspondence Analysis (CCA); it was indicated the most important environmental gradients those control the vegetation composition and the distribution pattern of species in Kharga Oasis, which were mainly related to gradients in soil moisture content and fine fractions. The present situation of Kharga Oasis urges the conservation of some old historic wells and the naturally growing open dom-palm forests before vanishing due to high human activities in the area.
\end{abstract}

Keywords: agro-ecosystem; arid environment; multivariate analysis; vegetation

\section{Introduction}

In the Sahara there are relatively few areas where potable water is found. An oasis (depression) is the most important landscape in arid areas. The vegetation cover and the vitality of the oasis can be used as indices to characterize the regional ecological environment (Jin et al., 2010). The Egyptian deserts (Eastern, Western and Sinai), as part of the Sahara, comprise about 95\% of the total country's land surface. The Western Desert covers two-thirds of Egypt (about 681,000 $\mathrm{km}^{2}$ ) as it extends from the Mediterranean coast to the border of Sudan for about $1,073 \mathrm{~km}$ and from the border of Libya to the Nile Valley for about 600 - 850 $\mathrm{km}$. Another salient feature, resulting from arid conditions, is the uniformity of the surface as compared with other parts of North Africa. Water is the principal controlling factor in all Saharan oases, except those where irrigation of the palm groves is not necessary. Sharing water is a common practice: a well rarely belongs to a single land-owner, but is shared among several land-owners according to rules which differ from one oasis to the other. The increase in human population of Egypt necessitates the expansion of the cultivated lands; therefore vast areas in these deserts were subjected to land reclamation, on both private and governmental schemes. The primitive vegetation of the uninhabited oases in Southern Egypt (Kehl, 1987) composed mainly of Dom palm (Hyphaene thebaica), several Acacia spp., Maerua, Capparis, Calotropis procera and Citrullus colocynthis.

During the last three decades, plant life of the major inhabited oases in the Western Desert has been intensively studied (Abd El-Ghani et al., 2017). In these oases, the 
364

population occupies small villages around the water resources, where agriculture is practiced. Other oases have been abandoned as their water supply has depleted. The general patterns of the habitats in the Egyptian oases were described by Abd El-Ghani and Fawzy (2006). Usually, zonation of the habitats were organized as follows: the out skirting desert (external zone), the arable lands including date-palm orchards and farmlands (inner zone) and the waste and salinized lands (middle zone).

Increasing the knowledge of different habitats with associated plant species in Kharga Oasis before their disappearance, due to high human impact in these areas, are highly recommended. In addition, in the South-Eastern part of the Western Desert, Egypt's giant Toshka project is in operation. With the completion of this project, the water of the Nile will be transferred from the Toshka depression (South-West of Aswan) through a long canal crossing the Oases of Kharga, Dakhla and Farafra. A total area of about 650,000 acres is expected to be under cultivation. Therefore, the present situation of Kharga Oasis urges the conservation of some old historic wells and the naturally growing open dom-palm forests.

In Egypt, Abd El-Ghani et al. (2011) and Salama et al. (2017) described the species-soil relationships in various crops and habitats of arable lands using multivariate methods. In the present paper, key questions were: (1) what is the present status of the floristic composition of Kharga Oasis? (2) What is the vegetation structure characterized different habitats? (3) What are the environmental factors that control the species distribution and diversity?

\section{Materials and Methods}

\section{Study area}

Kharga Oasis (or the Southern Oasis) is the largest of the oases of the Western Desert situated in the dry rainless part of the Great Sahara. It is $224 \mathrm{~km}$ West of Assiut City and $104 \mathrm{~km}$ East of Dakhla Oasis (Fig. 1). The desert lands extend between latitudes $24^{\circ} 30^{\prime}$ and $25^{\circ} 40^{\prime} \mathrm{N}$ and longitudes $30^{\circ}$ and $31^{\circ} \mathrm{E}$. The depression is long and narrow in shape, extends for about $185 \mathrm{~km}$ from North to South and between 15 and $30 \mathrm{~km}$ from East to West with a total surface area of more than $3,000 \mathrm{~km}^{2}$, with the cultivated area representing only $1 \%$ of the total. The lowest part of the Kharga Oasis is found around $18 \mathrm{~m}$ below sea level. Mobile sand dunes of the Barchan type are of frequent occurrence. Their movement (10-20 $\mathrm{m}$ year $\left.{ }^{-1}\right)$ across the floor swamps, cultivated land, wells, roads and buildings is remarkable.

Agriculture is mainly dependent on underground water from several wells. As a result of digging new deep wells $(250$ $-850 \mathrm{~m}$ ), most of the old wells have been neglected either because of their overwhelming by drifted sand, or through the decrease in the artesian pressure which could no longer raise the water to the surface. The principal crops are clover, wheat, barley, broad beans and lentil as winter crops. Summer crops include maize as a major crop. Yet, the perennial forage crop alfa-alfa (Medicago sativa L.) is cultivated in few plots.

The essential cash-crop is date palms, where its orchards constitute the majority of the cultivated lands. Under the severe arid conditions (high temperature and evaporation rate) prevailed in Kharga Oasis and the lack of a drainage system, flooding of the soil with slightly saline artesian water increases rapidly its salinity. Besides, no good drainage system is found in the agro-ecosystem and water drained directly to the adjacent lands. Therefore, vast areas of its land become salinized covered with salt crust are of frequent occurrence.

Rainfall is erratic; almost zero $\left(\mathrm{mm}\right.$ year $\left.{ }^{-1}\right)$ whereas the mean annual relative humidity is lower in summer (26 $32 \%)$ than in winter $(53-60 \%)$. Temperature is moderate in winter: absolute minimum $6.0-4.8^{\circ} \mathrm{C}$ and maximum 22.1-21.5 ${ }^{\circ} \mathrm{C}$, but rises very high in summer: absolute minimum $23.4-23.1^{\circ} \mathrm{C}$ and maximum $39.2-39.5^{\circ} \mathrm{C}$. The recorded extreme maxima of about $50^{\circ} \mathrm{C}$ are not unusual. According to meteorological data (2012-2016), the mean temperature ranged between $43{ }^{\circ} \mathrm{C}$ (June 2016 and August 2015) to $5^{\circ} \mathrm{C}$ in January 2012. In the meantime, the relative humidity $(\mathrm{RH})$ varied markedly according to the latitude, longitude and the different seasons of the year. It ranged between 66\% during December 2015 and 7\% in June and April 2016.

\section{Procedures of vegetation sampling}

During the growing seasons of 2015 and 2016, vegetation was sampled from 89 permanently visited stands in 12 sites situated along N-S line transect across Kharga Oasis, and extending for about $185 \mathrm{~km}$ (Fig. 1) to cover as much as possible the physiognomic variation in habitats. The area of each stand was around $20 \times 100 \mathrm{~m}$ that approximates the minimal area of species associations in the study area. Four habitats were recognized in this study; from

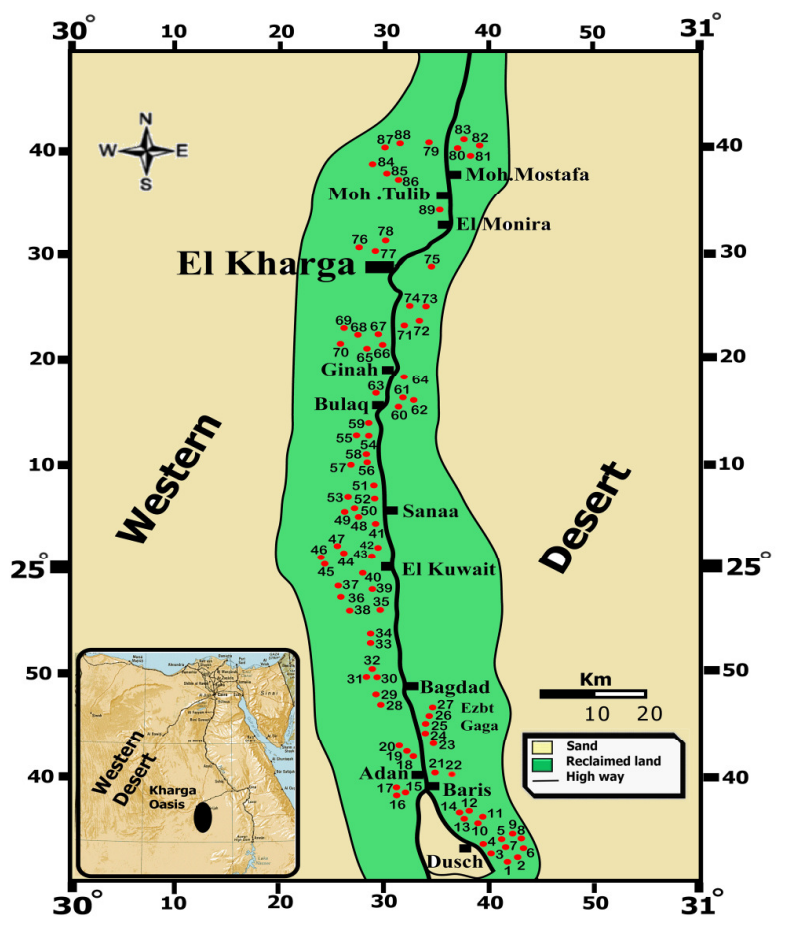

Fig. 1. Location map of Kharga Oasis, showing the distribution of the studied stands 
inner to outer zones: farmlands and palm orchards represent the inner zone, the salinized lands (not saltmarshes) in the middle, and the outskirting (bounding) desert in the outer zone. The farmlands included the major crops: wheat (Triticum aestivum L.), millet (Sorghum bicolor (L.) Moench, and the perennial alfa-alfa (Medicago sativa L.). In each of the studied stand, presence or absence of plant species was recorded using a number of permanent stands randomly positioned and representing the variation in the floristic composition of these habitats. The studied stands covered the four recognized habitats and distributed as follows: 38 in farmlands, 17 in palm orchards, 23 in waste-saline lands and 11 in the out-skirting deserts.

Presence percentages (P\%) of each species in each habitat was calculated as the total number of stands where a species was recorded, divided by the total number of monitored stands inside the habitat.

Specimens of each species were collected, then identified at the Herbarium of Cairo University (CAI) and duplicates were deposited at Assiut University Herbarium (AST). Taxonomic nomenclature was according to Täckholm (1974) and updated by Boulos (1999 - 2005, 2009).

\section{Soil analysis}

At each of the 89 stands, three soil samples $(0-50 \mathrm{~cm})$ were collected, mixed to form one composite sample, airdried, thoroughly mixed and passed through a $2 \mathrm{~mm}$ sieve to remove large gravels, plant remains and debris, then packed in plastic bags, ready for physical and chemical analysis. Three replicates were analyzed for each sample measurement. The soil texture was determined by the sieving method and the amount of each fraction was expressed as percentage of the original weight using the method of Ryan et al. (1996).

Water content of the soil samples was determined by weighing the fresh soil sample then drying it in an electric oven at $105^{\circ} \mathrm{C}$ for the constant dry weight, and then the dry weight was determined (Kapur and Govil, 2000). The extracts (1:5) were prepared by shaking $20 \mathrm{~g}$ of the dry soil with $100 \mathrm{ml}$ distilled water for one hour and filtration to obtain a clear filtrate that was used for determination of chemical properties.

Soil reaction $(\mathrm{pH})$ was determined in the soil extract using an electric $\mathrm{pH}$-meter (Model Hanna $\mathrm{pH} 211$ ).

The specific electrical conductance (EC) in water samples was measured by means of conductivity meter (Model 4310 JEN WAY).

Sodium and potassium were determined by the flame emission technique (Model Carl-Zeiss DR LANGE M7D) according to Williams and Twine (1960). Calcium and Magnesium were determined volumetrically by the versene titration method, chlorides were volumetrically determined as $\mathrm{AgCl}$ and bicarbonates were estimated by titration using the method described by Jackson (1967). Sulfates were estimated by turbidimetry with $\mathrm{BaSO}_{4}$ according to Bardsley and Lancaster (1965), phosphates were determined calorimetrically as phospho-molybdate according to Woods and Mellon (1941), organic matter was determined in the soil samples according to Walkley and Black (1934) by the dichromate oxidation method.

\section{Classification and ordination}

Both classification and ordination techniques were employed to the vegetation data. To avoid distortion, species present within 1-5 stands were eliminated from the dataset.

Therefore, a floristic presence/absence data matrix consisting of 89 species and 84 stands was subjected to cluster analysis using a Bray-Curtis similarity distance (Ludwig and Reynolds, 1988) with the software PAST version 2.11 for Windows (Hammer et al., 2001). The matrix was then analyzed with Detrended Correspondence Analysis (DCA) variance regression ordination, using the Sørensen coefficient as the distance measure, to check the magnitude of change in species composition along the soil gradients (McCune and Mefford, 1999). The Bray-Curtis variance regression ordination was used because it is considered an effective technique for community analyses and for revealing ecological gradients.

\section{Soil-vegetation relationships}

The computer program CANOCO software version 3.12 (Ter Braak, 1990) was used for all ordinations and plotted with CANODRAW version 3.0. Preliminary analyses were made by applying the default option of the Detrended Correspondence Analysis (DCA; Hill and Gauch, 1980) to check the magnitude of change in species composition along the first ordination axis (i.e., gradient length in standard deviation (SD) units). In the present study, DCA estimated the compositional gradient in the vegetation data to be 3.5 SD-units, thus Canonical Correspondence Analysis (CCA) can be used for direct gradient analysis (Ter Braak and Prentice, 1988).

Prior to the CCA analysis, all data variables were assessed for normality using SPSS version 10.0 and appropriate transformations were performed when necessary to improve normality. Seventeen soil variables were included: electrical conductivity (EC), $\mathrm{pH}$, organic matter (OM), water content (WC), gravel, coarse sand (CS), fine sand (FS), silt, clay, bicarbonates, Calcium, Magnesium, Sodium, chlorides, Potassium, sulfates and phosphates. All the default settings were used for CCA and a Monte Carlo permutation test (Ter Braak, 1990) was used to test for significance of the eigenvalues of the first canonical axis, and to test the significance of the effect on the species of the studied soil variables.

The vegetation groups produced from cluster analysis were subjected to an ANOVA based on soil variables to find out whether there are significant variations among groups.

\section{Species diversity}

Two species diversity measures were employed. Species richness (SR) within each separated vegetation group was calculated as the average number of species per stand.

The Shannon-Wiener diversity index $\left(H^{\prime}\right)$ was calculated from the formula:

$\mathrm{H}^{\prime}=-\sum_{\mathrm{i}}^{\mathrm{S}} \mathrm{P}_{\mathrm{i}} \log _{2} \mathrm{P}_{\mathrm{i}}$ (Pielou, 1975), where $S$ is the total number of species and $P_{i}$ is the presence percentage of the $i$ the species. 


\section{Results}

\section{Floristic relations}

In total, 122 species from 35 families and 102 genera represented the flora of the study area. Poaceae (25 species), Fabaceae (15 species) and Asteraceae (11 species) constituted $47 \%$ of the recorded flora, while 59 species $(48.4 \%)$ were included in smaller size families (with $1-5$ species). Annuals and perennials were equally represented by 61 species. Therophytes dominated the life form spectrum (61 species), followed by hemicryptophytes, geophytes and phanerophytes (16 species for each). Cuscuta campestris was the only recorded parasite. Cosmopolitan, palaeotropical and pantropical species were represented by 41 species (33.6\%), while pure Saharo-Arabian species dominated the monoregional taxa (14 out of 25$)$. It is worthy to note that bi- and pluri-regional Mediterranean and Saharo-Arabian species formed $36.9 \%$ of the total flora.

The total number of species varied along the habitat gradient from the outer to the inner zone: 39 species in the bounding desert, 73 in the salinized lands, 79 in the datepalm orchards and 86 in the farmlands. A detailed account on the spatial and temporal floristic composition within different habitats will be published separately.

\section{Classification of the vegetation}

After removal of species with presence values $1-5 \%$, a presence/absence data-set of 89 species recorded in the 84 stands was subjected to classification using Bray-Curtis cluster analysis, which produced 4 vegetation groups (A-D) (Table 1, Fig. 2). These vegetation groups were named after the dominant species that have the highest presence values (P\%) and linked to a certain habitat. Twenty species were recorded in all groups and constituted the ubiquitous species, represented in the four major habitats (farmlands, date-palm orchards, salinized lands and the desert outskirts). It can also be noted that most of stands of group $\mathrm{C}$ were located in the proximity of the center of the oasis (between Ginah and El-Kuwait Villages), while stands of group B occurred closer to the North of the oasis (El-Monira Village; Fig. 1).

Group A: 53 species in 16 stands; was dominated by Cynodon dactylon and Calotropis procera, represented desert outskirts, salinized lands and some date-palm orchards adjacent to these habitats. Stands of this group inhabited soil with the highest percentages of silt and clay and the lowest values of gravels, coarse sand, fine sand, WC and
OM, EC, and other nutrients. Co-dominant species were, amongst others, Alhagi graecorum, Phoenix dactylifera, Launaea mucronata, Brassica tournefortii and Trichodesma africanum (Table 1). Fagonia arabica and Plantago amplexicaulis were confined to this group also. Sporadic species included Convolvulus arvensis, Hyoscyamus muticus, Pulicaria incisa, Zygophyllum coccineum, Boerhavia repens subsp. viscosa and Juncus rigidus.

Group B: 51 species in 23 stands represented the waste and saline land habitats that characterized by Tamarix nilotica and Alhagi graecorum inhabited saline soil rich in its nutrient contents (anions and cations). This group was the least diversified among the others, with the lowest species richness $\left(10.30 \pm 3.30\right.$ species stands $\left.{ }^{-1}\right)$ and ShannonWiener diversity index $(2.28 \pm 0.3)$. Phragmites australis, Imperata cylindrica, Phoenix dactylifera and Cynodon dactylon were the co-dominant species. Some salt-tolerant species such as Sporobolus spicatus, Juncus rigidus, Suaeda fruiticosa and Schoenoplectus litoralis were recorded in this group. Sporadic species included, amongst others, Pennisetum divisum, Ambrosia maritima, Leptochloa fusca, Ziziphus spina-christi and Gossypium herbaceum.

Group C: 78 species in 39 stands represented the farmland habitat, was dominated by Malva parviflora and Sonchus oleraceus. This group was the most diversified with species richness of $15.69 \pm 4.56$ species stands ${ }^{-1}$ and Shannon-Wiener diversity index of $2.71 \pm 0.32$ (Table 2). The highest soil contents of fine sand, WC and OM characterized this group. Co-dominant species were mainly common weeds of arable lands and included Cynodon dactylon, Chenopodium murale, Convolvulus arvensis, Cichorium endivia subsp. divaricatum and Echinochloa colona. Consistent species to this group were, amongst others, Ammi majus, Sinapis arvensis, Trianthema portulacastrum, Convolvulus fatmensis, Dinebra retraflexa and Paspalidium geminatum (Table 1).

Group D: 42 species from 6 stands of date-palm orchards were noted; the group was dominated by Cynodon dactylon $(\mathrm{P}=100 \%)$ with relatively species richness $(14.83$ \pm 7.99 species stand $^{-1}$ ) and Shannon-Wiener diversity (2.59 $\pm 0.49)$. The soil of these stands showed an intermediate level of contents among other groups, while they had the lowest $\mathrm{Ca}, \mathrm{Mg}$ and $\mathrm{Cl}$ contents (Table 2). Conyza bonariensis, Digitaria sanguinalis, Setaria verticillata were the co-dominants, while consistent species were Cyperus

Table 1. Floristic composition of the vegetation groups (A-D) with the presence percentages (P\%) of each species

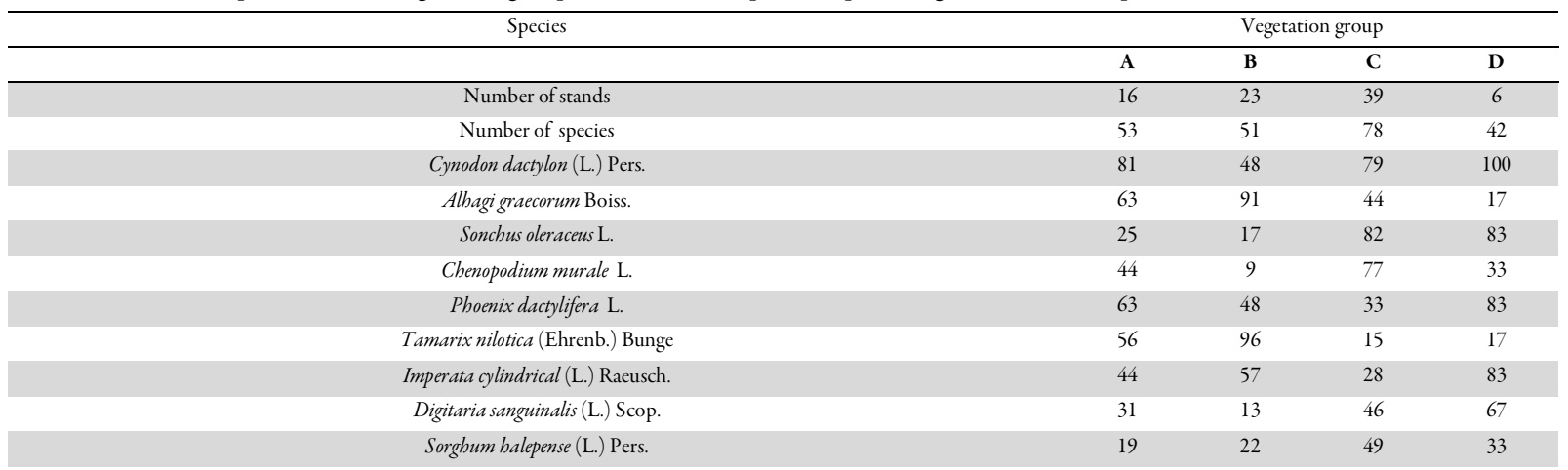




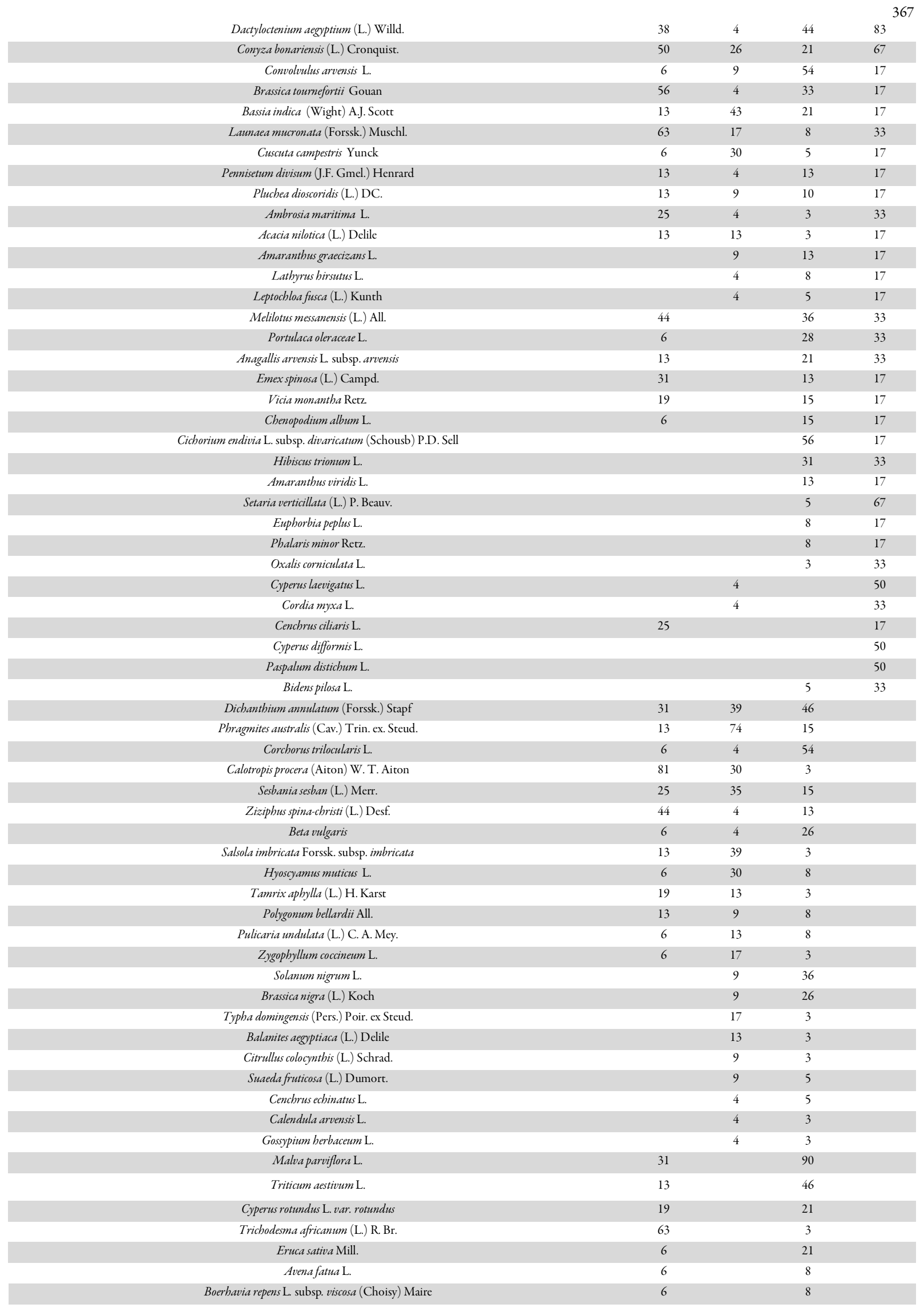


368

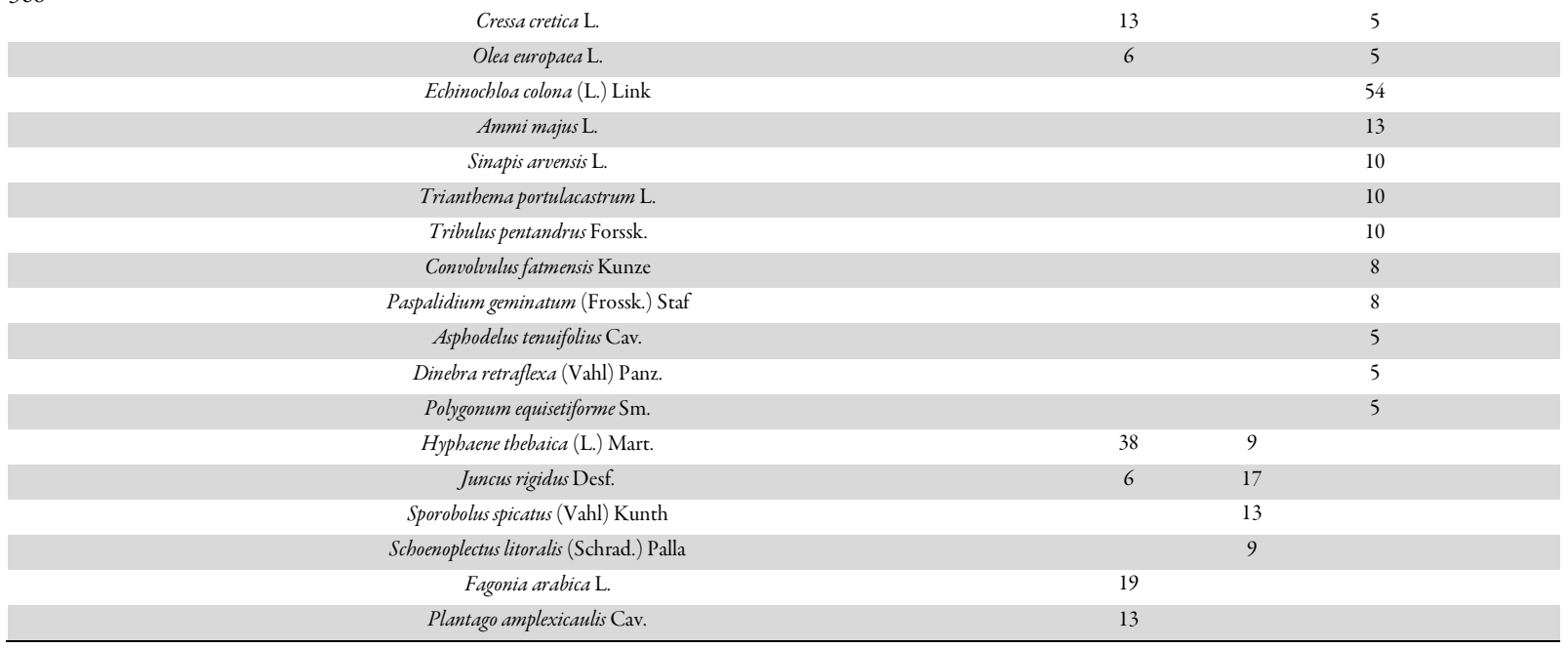

Table 2. Mean values, standard deviations and ANOVA values of the soil variables in the vegetation groups (A-D) of the study area $\left({ }^{* *}=\mathrm{p}<0.01,{ }^{*}=\mathrm{p}\right.$ $<0.05)$

\begin{tabular}{|c|c|c|c|c|c|c|c|c|c|c|c|c|c|c|}
\hline \multirow{3}{*}{$\begin{array}{l}\text { Soil variables } \\
\text { Gravel (\%) }\end{array}$} & \multicolumn{12}{|c|}{ Vegetation group } & \multirow{3}{*}{$\begin{array}{l}\text { F value } \\
7.027^{* *}\end{array}$} & \multirow{3}{*}{$\begin{array}{c}P \\
0.001\end{array}$} \\
\hline & \multicolumn{3}{|c|}{ A } & \multicolumn{3}{|c|}{$\mathrm{B}$} & \multicolumn{3}{|c|}{$\mathrm{C}$} & \multicolumn{3}{|c|}{$\mathrm{D}$} & & \\
\hline & 1.10 & \pm & 1.63 & 9.49 & \pm & 13.22 & 4.09 & \pm & 8.85 & 2.93 & \pm & 6.99 & & \\
\hline Coarse sand (CS) (\%) & 9.95 & \pm & 8.67 & 18.64 & \pm & 12.85 & 15.40 & \pm & 8.92 & 13.82 & \pm & 9.25 & $7.625^{* *}$ & 0.001 \\
\hline Fine Sand (FS) (\%) & 10.85 & \pm & 5.98 & 11.25 & \pm & 6.98 & 15.25 & \pm & 6.78 & 13.11 & \pm & 4.56 & $2.869^{*}$ & 0.042 \\
\hline Silt (\%) & 58.29 & \pm & 13.03 & 44.17 & \pm & 17.42 & 49.71 & \pm & 11.46 & 53.57 & \pm & 14.37 & 2.357 & 0.078 \\
\hline Clay $(\%)$ & 19.80 & \pm & 4.11 & 16.46 & \pm & 6.11 & 15.56 & \pm & 5.11 & 16.57 & \pm & 2.47 & 2.617 & 0.057 \\
\hline Water content (WC) (\%) & 2.95 & \pm & 3.85 & 6.57 & \pm & 9.97 & 12.53 & \pm & 7.17 & 10.83 & \pm & 4.96 & $3.429^{*}$ & 0.021 \\
\hline Organic matter (OM) (\%) & 0.40 & \pm & 0.36 & 0.50 & \pm & 0.36 & 0.67 & \pm & 0.39 & 0.62 & \pm & 0.38 & 0.344 & 0.794 \\
\hline $\mathrm{pH}$ & 7.88 & \pm & 0.28 & 7.85 & \pm & 0.44 & 7.93 & \pm & 0.27 & 7.94 & \pm & 0.18 & 2.626 & 0.056 \\
\hline Electrical conductivity (EC) $\left(\mathrm{mS} \mathrm{cm}^{-1}\right)$ & 0.63 & \pm & 0.79 & 4.11 & \pm & 5.55 & 0.71 & \pm & 0.81 & 0.71 & \pm & 0.90 & $7.285^{* *}$ & 0.001 \\
\hline $\mathrm{Na}\left(\mathrm{mg} \cdot \mathrm{g}^{1} \mathrm{~d}\right.$ wt soil $)$ & 0.84 & \pm & 1.11 & 5.78 & \pm & 6.72 & 0.93 & \pm & 0.96 & 0.96 & \pm & 1.74 & $7.286^{* *}$ & 0.001 \\
\hline $\mathrm{K}$ (mg.g ${ }^{-1} \mathrm{~d}$ wt soil $)$ & 0.19 & \pm & 0.13 & 0.66 & \pm & 1.17 & 0.25 & \pm & 0.26 & 0.28 & \pm & 0.38 & 2.328 & 0.081 \\
\hline $\mathrm{Ca}\left(\mathrm{mg} \cdot \mathrm{g}^{-1} \mathrm{~d}\right.$ wt soil $)$ & 0.60 & \pm & 0.54 & 2.12 & \pm & 2.23 & 0.63 & \pm & 0.77 & 0.45 & \pm & 0.37 & $9.93^{* *}$ & 0.001 \\
\hline $\mathrm{Mg}\left(\mathrm{mg} \cdot \mathrm{g}^{-1} \mathrm{~d}\right.$ wt soil $)$ & 0.30 & \pm & 0.16 & 1.03 & \pm & 1.29 & 0.34 & \pm & 0.18 & 0.29 & \pm & 0.06 & 2.444 & 0.070 \\
\hline $\mathrm{Cl}$ (mg. $\mathrm{g}^{-1} \mathrm{~d}$ wt soil $)$ & 1.02 & \pm & 1.43 & 11.17 & \pm & 17.09 & 1.06 & \pm & 1.32 & 0.93 & \pm & 1.42 & $7.478^{* *}$ & 0.001 \\
\hline $\mathrm{HCO}_{3}$ (mg.g-1 d wt soil) & 0.54 & \pm & 0.34 & 0.81 & \pm & 0.42 & 0.75 & \pm & 0.41 & 0.55 & \pm & 0.29 & $5.9^{* *}$ & 0.001 \\
\hline $\mathrm{PO}_{4}\left(\mu \mathrm{gg}^{-1} \mathrm{dwt}\right.$ soil $)$ & 6.21 & \pm & 10.14 & 2.61 & \pm & 3.14 & 6.65 & \pm & 7.21 & 5.64 & \pm & 4.90 & $6.997^{* *}$ & 0.001 \\
\hline $\mathrm{SO}_{4}\left(\mu \mathrm{gg}^{-1} \mathrm{~d}\right.$ wt soil $)$ & 9.33 & \pm & 12.08 & 29.61 & \pm & 26.28 & 11.53 & \pm & 11.11 & 13.50 & \pm & 15.16 & 1.934 & 0.131 \\
\hline Species richness (SR) & 13.69 & \pm & 4.27 & 10.30 & \pm & 3.30 & 15.69 & \pm & 4.56 & 14.83 & \pm & 7.99 & 1.739 & 0.166 \\
\hline Shannon-Wiener index $\left(\mathrm{H}^{\prime}\right)$ & 2.57 & \pm & 0.33 & 2.28 & \pm & 0.34 & 2.71 & \pm & 0.32 & 2.59 & \pm & 0.49 & $6.643^{* *}$ & 0.001 \\
\hline
\end{tabular}

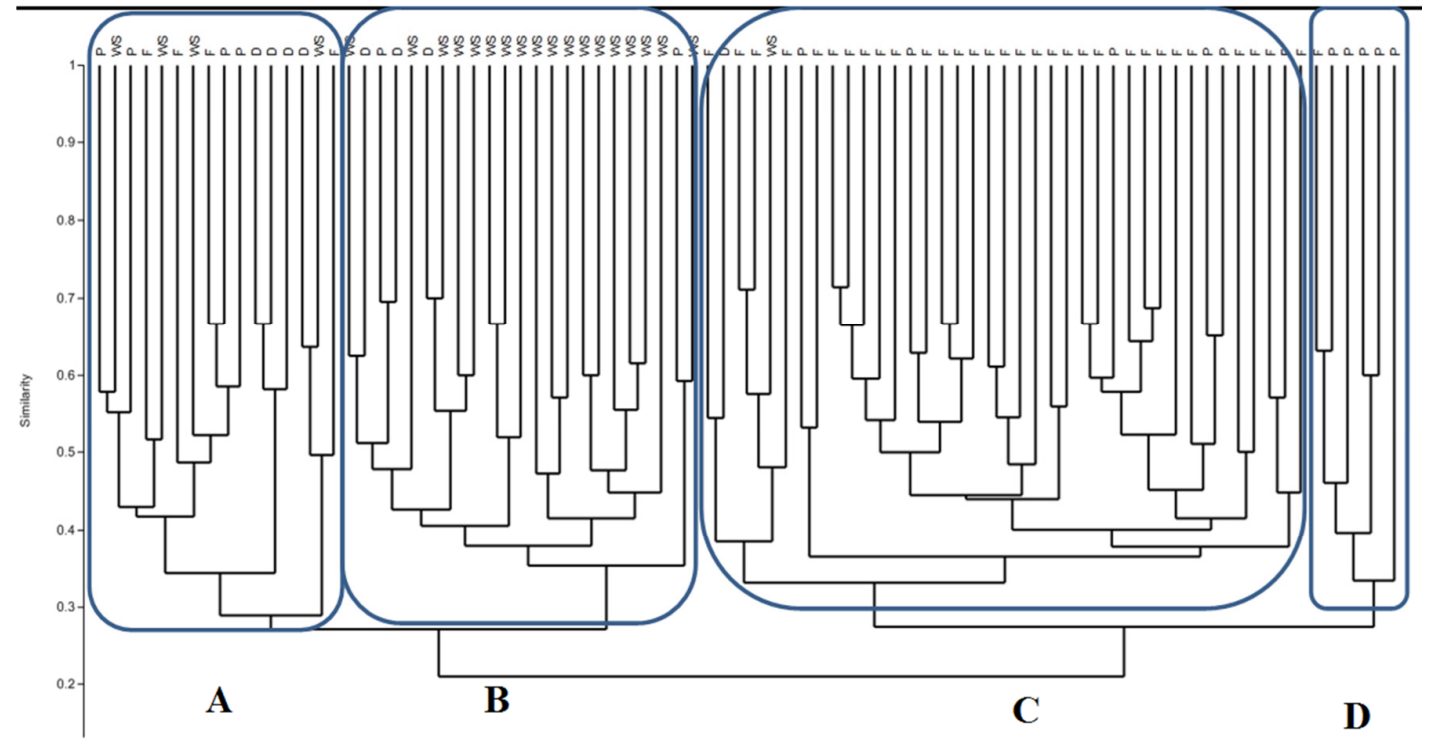

Fig. 2.The relationship between the four vegetation groups (A-D) generated after application of cluster analysis; $\mathrm{P}=\mathrm{Palm}$ orchards, $\mathrm{F}=$ Farmlands, $\mathrm{S}=$ Saline lands, $\mathrm{W}=$ Waste lands, $\mathrm{D}=$ Desert outskirts 
difformis and Paspalum distichum. Twenty sporadic species were recorded (e.g. Tamarix nilotica, Alhagi graecorum, Pluchea dioscoridis, Emex spinosa, Bassia indica and Cenchrus ciliaris).

Significant differences in the examined environmental variables within the separated vegetation groups were demonstrated in Table 2. Most of these variables showed significant (fine sand and WC) or high significant differences (gravels, coarse sand, EC, $\mathrm{Na}, \mathrm{Ca}, \mathrm{Cl}, \mathrm{PO}_{4}$ and $\mathrm{HCO}_{3}$ ) between groups.

\section{Stand ordination}

Application of Detrended Correspondence Analysis (DCA) to the vegetation data of the study area revealed the segregation of the four vegetation groups along the first two axes (Eigenvalues $=0.436$ for axis 1 and 0.313 for axis 2), with the lengths of gradient 3.86 for axis 1 and 2.98 for axis 2 (Fig. 3). The cumulative percentage variance of species data of the first two DCA axes was $22.8 \%$. Stands of the four groups represented the recognized four habitats showed clear segregation, i.e. the communities of deserts, wastelands and saline lands (groups A and B) tended to be near to the positive end of the first axis. Meanwhile, the cultivated lands (farmlands and date-palm orchards; groups $\mathrm{C}$ and D) separated along the negative end of axis 1.

\section{Soil characteristics}

The relationship between the vegetation and soil variables was studied using Canonical Correspondence Analysis (CCA). Fig. 4 showed the CCA ordination biplot with vegetation groups (A-D) and the examined soil variables. It can be noted that, stands of group $A$ and $B$ were highly correlated with clay, gravels and all most of the measured cations and anions (i.e. $\mathrm{Na}, \mathrm{K}, \mathrm{Cl}, \mathrm{Ca}, \mathrm{Mg}$ and $\mathrm{SO}_{4}$ ) while those of group $\mathrm{C}$ showed a correlation with the soil fractions (silt, clay, fine sand, coarse sand and gravels), water content and $\mathrm{PO}_{4}$. Also, the stands of group $\mathrm{D}$ showed high correlation with the soil fractions and $\mathrm{pH}$. CCA axis 1 was highly positively correlated with $\mathrm{Na}$ and highly negatively correlated with WC and this axis can be inferred as Na-WC gradient (Table 3). CCA axis 2 was highly positively correlated with $\mathrm{HCO}_{3}$ and highly negatively with silt $\left(\mathrm{HCO}_{3}\right.$-silt gradient). A test for significance with an unrestricted Monte Carlo permutation test (499 permutation) for the eigenvalue of axis 1 found to be significant $(p=0.002)$.

Table 3. Interset correlation of CCA analysis for the soil variables, together with eigenvalues and species-environment correlations (for soil abbreviations, see Table 2)

\begin{tabular}{|c|c|c|c|}
\hline \multicolumn{2}{|c|}{ CCA Axes } & Axl & Ax2 \\
\hline \multicolumn{2}{|c|}{ Species- environment correlations } & 0.824 & 0.790 \\
\hline \multicolumn{2}{|c|}{ Eigenvalues } & 0.264 & 0.163 \\
\hline Gravels & & 0.163 & 0.267 \\
\hline CS & & 0.060 & 0.301 \\
\hline FS & & -0.331 & 0.427 \\
\hline Silt & $(\%)$ & -0.043 & -0.470 \\
\hline Clay & & 0.11 & -0.320 \\
\hline WC & & -0.481 & 0.2933 \\
\hline $\mathrm{OM}$ & & -0.444 & -0.137 \\
\hline $\mathrm{pH}$ & & -0.186 & -0.248 \\
\hline $\mathrm{EC}$ & $\left(\mathrm{mS} \mathrm{cm}^{-1}\right)$ & 0.483 & 0.122 \\
\hline $\mathrm{Na}$ & & 0.627 & 0.180 \\
\hline $\mathrm{K}$ & & 0.404 & 0.066 \\
\hline $\mathrm{Ca}$ & $\left(\mathrm{mg} \cdot \mathrm{g}^{-1} \mathrm{dwt}\right)$ & 0.615 & 0.125 \\
\hline $\mathrm{Mg}$ & & 0.546 & 0.161 \\
\hline $\mathrm{Cl}$ & & 0.474 & 0.159 \\
\hline $\mathrm{HCO}_{3}$ & & -0.062 & 0.723 \\
\hline $\mathrm{PO}_{4}$ & $\left(\mu g \cdot g^{-1} d w t\right)$ & -0.317 & -0.080 \\
\hline $\mathrm{SO}_{4}$ & $\left(\mu \mathrm{g} \cdot \mathrm{g}^{-1} \mathrm{dwt}\right)$ & 0.587 & 0.054 \\
\hline
\end{tabular}

Table 4. Spearman rank correlations between diversity indices and the environmental variables $\left({ }^{*}=p<0.05,{ }^{* *}=p<0.01\right.$ ) (for soil abbreviations, see Table 2)

\begin{tabular}{|c|c|c|}
\hline \multirow{2}{*}{ Soil variables } & \multicolumn{2}{|c|}{ Diversity } \\
\hline & SR & $\mathrm{H}^{\prime}$ \\
\hline Gravels & -0.046 & -0.045 \\
\hline CS & -0.187 & -0.192 \\
\hline FS & 0.045 & 0.054 \\
\hline Silt & 0.16 & 0.163 \\
\hline Clay & -0.042 & -0.052 \\
\hline WC & $0.240^{*}$ & $0.254^{*}$ \\
\hline $\mathrm{pH}$ & 0.152 & 0.169 \\
\hline $\mathrm{EC}$ & $-0.216^{*}$ & $-0.223^{*}$ \\
\hline $\mathrm{OM}$ & 0.181 & 0.199 \\
\hline $\mathrm{Na}$ & $-0.246^{*}$ & $-0.255^{*}$ \\
\hline $\mathrm{K}$ & -0.124 & -0.117 \\
\hline $\mathrm{Ca}$ & $-0.306^{* *}$ & $-.0338^{* *}$ \\
\hline $\mathrm{Mg}$ & -0.191 & -0.188 \\
\hline $\mathrm{Cl}$ & -0.167 & -0.160 \\
\hline $\mathrm{HCO}_{3}$ & -0.014 & -0.021 \\
\hline $\mathrm{PO}_{4}$ & $0.244^{*}$ & $0.236^{*}$ \\
\hline $\mathrm{SO}_{4}$ & $-0.315^{* *}$ & $-0.352^{* *}$ \\
\hline
\end{tabular}


370

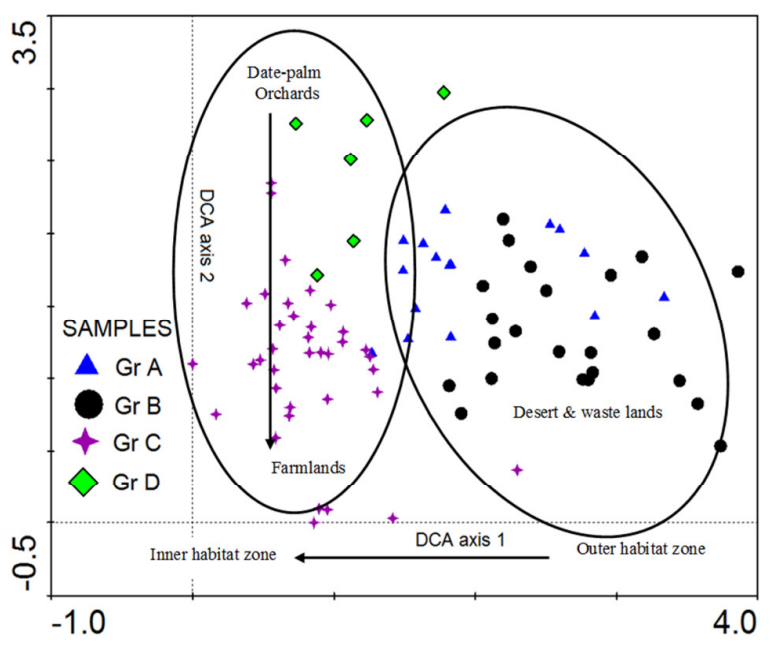

Fig. 3. DCA diagram showing the distribution of the studied 84 stands within their vegetation groups (A-D)

\section{Species diversity and soil attributes}

Difference in species richness (SR) among the 4 vegetation groups was not significant (Table 4), while Shannon-Wiener index $\left(\mathrm{H}^{\prime}\right)$ showed high significant variations $(p=0.001)$. Both indices showed high significant negative correlations $(p<0.01)$ with Calcium and sulfates, and positively significant correlation $(p<0.05)$ with water content (WC) and phosphates, while negatively correlated with electrical conductivity (EC) and Sodium.

\section{Discussion}

Based on the number of species, Poaceae, Asteraceae and Fabaceae were the major families, which formed $47 \%$ of the total flora of the study area and were also reported to be the most frequent families in other parts of Egypt (Shaheen, 2002), Pakistan (Enright, 2005), as well as in Ethiopia (Firehun and Tamado, 2006). In the Mediterranean North African flora, Quézel (1978) indicated the importance of these families and were found to be the most frequent families in the tropics (Tamado and Milberg, 2000).

The vegetation in the oases (depressions) of the Western Desert of Egypt is unique (Abd El-Ghani et al., 2017) and composed mainly of two complementary landscape units: the irrigation system and the arable lands. Detailed information on floristic composition and habitat characteristics included in each of these units were described by Abd El-Ghani and Fawzy (2006), who recognized five main habitats; each had its preferential species: farmlands, canal banks, reclaimed lands, wastelands and water bodies. On the other hand, Abd El-Ghnai and Fahmy (1998) recognized two main ecosystems in the Feiran oasis of South Sinai: the bounding desert and the cultivated areas. Similarly, the four recognized habitats in this work were congruent with other relevant studies which are relatively simple, and included species capable of surviving and withstanding harsh environmental conditions.

The zonation of habitats within the Egyptian oases of the Western Desert is noticeable. Abd El-Ghani (1992)

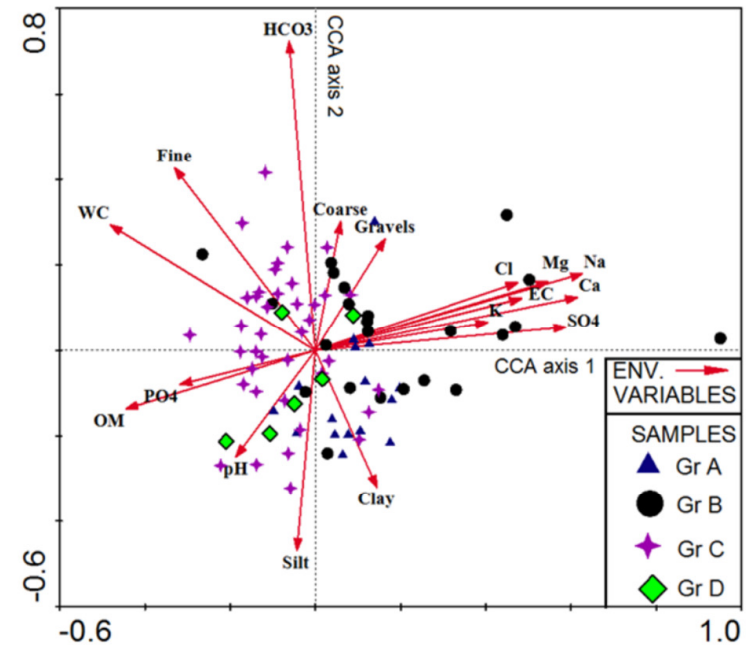

Fig. 4. Canonical correspondence analysis (CCA) biplot along axes 1 and 2, showing the distribution of the 84 stands and their correlations with the environmental variables and vegetation groups (A-D)

indicated this phenomenon and revealed the presence of 3 concentric zone (from outside to inside): (1) the outer desert boundaries (outskirting desert), (2) the middle zone that occupied by the salinized and waste lands which receive the drainage water from (3) the inner cultivated lands (farmlands and date-palm orchards). The arrangement of habitat zones along the first DCA axis can be noticed: outer zone (desert outskirts), middle zone (waste and salinized lands) and inner zone (arable lands). On the other hand, farmlands and date-palm orchard groups were separated from each other along the second DCA axis. Similarly, this axis represented a gradient along which the arable land habitat (inner zone) can be also separated. Such concentric zonation of the vegetation was also identified and described from Moghra Oasis (Abd El-Ghani, 1992) in the Western Desert of Egypt and in the neighboring countries of the arid region: Cornett (2008) in a fan palm oasis in the Sonoran Desert of North America; Vetaas et al. (2012) in the mist Oasis of the Sudan.

The variations in microclimatic conditions and edaphic factors resulted in the identification of vegetation patterns (James et al., 2006) of the plant communities in Kharga Oasis. In terms of classification, four vegetation groups (plant communities) were identified: Cyndon dactylonCalotropus procera (group A), Tamrix nilotica-Alhagi graecorum (group B), Malva parviflora-Sonchus oleraceus (group C) and Cynodon dactylon (group D).

Most of the identified vegetation groups and their associated species were more or less comparable with those recorded in other relevant studies in Israel (Naveh and Whittaker, 1979) and Saudi Arabia (Alatar et al., 2012). The dominant species (Cynodon dactylon, Malva parviflora and Sonchus oleraceus) are among the common weeds of arable lands of Egypt (Salama et al., 2017). They were recorded in all the recognized habitats as they have a wide range of distribution often caused by phenotypic plasticity and heterogeneity. 
The habitat type has direct effect on the dominance relations among different vegetation composition. Moreover, the weedy species replace the natural plant communities and this is a widespread phenomenon (Yang et al., 2006). This result goes in line with Abd El-Ghani and El-Sawaf (2004) in the increase of the number of species recorded in both farmland and date-palm orchard habitats. Desert land reclamation processes that occurred in the deltaic part of Wadi Qena and its tributaries and the transportation of soil from old cultivated lands adjacent to the River Nile can be attributed to the high contribution of weed species (68\%) in the total flora. It has been found that species richness in cultivated lands is higher in complex and heterogeneous landscapes.

The floristic composition of the vegetation groups in the study area included several weed species besides some desert species that grow in the surrounding natural desert habitats as Citrullus colocynthis, Alhagi, Tamarix nilotica, T. aphyla and Zygophyllum coccineum. This suggests that the human practices in land reclamation in Kharga Oasis entails weed species replacing the natural xeric plant communities. Also, several authors reported similar conclusions (e.g. Baessler and Klotz, 2006; Abd El-Ghani et al., 2015). On the other hand, the psammophytes (e.g. Zygophyllum coccinum, Citrullus colocynthis and Senna italica) and halophytes (e.g. Sporobolus spicatus and Aeluropus lagopoides) were recorded in the out-skirting deserts and waste-saline lands, respectively. This may due to the differences between the ecological factors between these habitats. Abd El-Ghani (1992) identified two main weed groups characterized the date palm orchards of Kharga Oasis: the first was dominated with Imperata cylindrica, Euphorbia peplus, Anagallis arvensis and Sonchus oleraceus, and the second with Alhagi graecorum, Conyza bonariensis and Prosopis farcta. The separated vegetation group (D) that identified from the date-palm orchards was, to some extent, similar to communities from two alliances described in Egypt by Kosinová (1975): Melilotion indici and Convolvulo (arvensis)-Rumicetum dentati mainly from areas along the Nile region. Also, this indicates that the floristic structure of the study area being more affected by human disturbances (Abd El-Ghani et al., 2011).

Canonical Correspondence Analysis indicated the most important environmental gradients those control the vegetation composition and the distribution pattern of species in Kharga Oasis were mainly related to gradients in soil moisture content and fine fractions. The first CCA axis was referred to as sodium-soil water content gradient, while axis 2 was referred to as bicarbonate-silt gradient. Variation in penetrability and soil depth affect the distribution of plant communities, as well as the growth of plants and root penetration and habit. Soil pockets in desert habitats are extremely important, as they offer a foothold for seedlings, usually have more plant available water and thus provide a favorable habitat for plant growth in an arid environment (Batanouny, 1983). This is consistent with relevant studies that concluded the importance of abiotic environmental factors such as percentage of surface sediments of different size classes, soil moisture, and other soil nutrients in the distribution of vegetation in the deserts of arid region (Qian et al., 2008; Abdel Khalik et al., 2013).
The variations in species richness and diversity may be attributed to the difference in soil characteristics, substrate discontinuities and the allelopathic effect of one or more invasive species depending on their relative dominance among other associated species (James et al., 2006). High level of species diversity would be brought about by a local differentiation in soil properties around individual plants, since heterogeneity of environments allows satisfaction of the requirements of many species within a community (Whittaker et al., 1977).

\section{Acknowledgements}

The present research received no specific grant from any funding agency in the public, commercial, or not-for-profit sectors.

\section{References}

Abd El-Ghani MM (1992). Flora and vegetation of Qara Oasis, Egypt. Phytocoenologia 21(1-2):1-14.

Abd El-Ghani MM, Fahmy AG (1998). Composition of and changes in the spontaneous flora of Feiran Oasis, $S$ Sinai, Egypt, in the last 60 years. Willdenowia 28:123-134. https://doi.org/10.3372/wi.28.2811.

Abd El-Ghani MM, El-Sawaf N (2004). Diversity and distribution of plant species in agro-ecosystems of Egypt. Systematics and Geography of Plants 319-336.

Abd El-Ghani MM, Fawzy AM (2006). Plant diversity around springs and wells in five oases of the Western Desert, Egypt. International Journal of Agriculture and Biology (Pakistan) 8:249-255.

Abd El-Ghani MM, Abo El-Kheir M, Abdel-Dayem M, El-Hamid M (2011). Vegetation analysis and soil characteristics of five common desert climbingplants in Egypt. Turkish Journal of Botany 35:561-580.

Abd El-Ghani MM, Hamdy RS, Hamed AB (2015). Habitat diversity and floristic analysis of Wadi El-Natrun Depression, Western Desert, Egypt. Phytologia Balcanica 21(3):351-366.

Abd El-Ghani MM, Huerta-Martínez FM, Hongyan L, Qureshi R (2017). Plant responses to hyperarid desert environments. Springer International Publishing ISSN:978-3-319-591346.

Abdel Khalik, KA, El-Sheikh M, El-Aidarous A (2013). Floristic diversity and vegetation analysis of Wadi Al-Noman, Mecca, Saudi Arabia. Turkish Journal of Botany 37(5):894907.

Alatar A, El-Sheikh M A, ThomasJ (2012). Vegetation analysis of Wadi AlJufair, a hyper-arid region in Najd, Saudi Arabia. Saudi Journal of Biological Sciences 19(3):357-368.

Bardsley CE, Lancaster JD (1965). Sulfur 1. Methods of soil analysis. Part 2. Chemical and microbiological properties, (methodsofsoilanb) pp 11021116.

Baessler C, Klotz S (2006). Effects of changes in agricultural land-use on landscape structure and arable weed vegetation over the last 50 years. Agriculture, Ecosystems and Environment 115(1-4):43-50.

Batanouny KH (1983). Human impact on desert vegetation. In: Holzner W, Werger MJA, Ikusima I (Eds). Man's impact on vegetation pp 139149.

Boulos L (1999-2005). Flora of Egypt. Vols. 14. Al Hadara Publishing, Cairo,Egypt 
372

Boulos L (2009). Flora of Egypt. Checklist. Revised Annotated Edition. Al Hadara Publishing, Cairo, Egypt.

Cornett JW (2008). The desert fan palm oasis. Arid land springs in North America: Ecology and conservation. The Arizona Sonora Desert Museum and the University of Arizona Press, Tucson, AZ .

Enright NJ, Miller BP, Akhter R (2005). Desert vegetation and vegetationenvironment relationships in Kirthar National Park, Sindh, Pakistan. Journal of AridEnvironments 61(3):397-418.

Firehun Y, Tamado T (2006). Weed flora in the Rift Valley sugarcane plantations of Ethiopia as influenced by soil types and agronomic practises. Weed Biology and Management 6(3):139-150.

Hammer O, Harper DAT, Ryan PD (2001). Paleontological statistics software: package for education and data analysis. Palaeontologia Electronica 4:1-9.

Hill MO, Gauch HG (1980). Detrended correspondence analysis: an improved ordination technique. Vegetatio 42:47-58.

Jackson ML (1967). Soil chemical analysis. Prentice-Hall of India, Private limitedNew Delhi pp 498

James JJ, Caird MA, DrenovskyRE, Sheley RL(2006). Influence of resource pulses and perennial neighbors on the establishment of an invasive annual grass in the Mojave Desert. Journal of Arid Environments 67:528-534.

Jin X, Schaepman M, Clevers J, Su Z, Hu G (2010). Correlation between annual runoff in the Heihe River to the vegetation cover in the Ejina Oasis (China). Arid Land Research and Management 24(1):31-41.

Kapur P, Govil SR (2000). Experimental plant ecology. CBS, Publisher and Distributors, Daryaganj, New Delhi(India).

Kehl H (1987). Zonation and establishment of vegetation in selected uninhabitedEgyptian and Sudanese oases. Catena 14(4):275-289.

Kosinová J (1975). Weed communities of winter crops in Egypt. Preslia 47:58-74.

LudwigJA, Reynolds JF (1988). Statistical ecology: a primer in methods and computing (Vol. 1).John Wiley \& Sons.

McCune B, Mefford MJ (1999). PC-ORD: multivariate analysis of ecological data; Version 4 for Windows; [User's Guide]. MjM software design.

Naveh Z, Whittaker RH (1979). Structural and floristic diversity of shrub lands and woodlands in northern Israel and other Mediterranean areas. PlantEcology 41(3):171-190.

Pielou EC (1975). Ecological diversity. New York, Wileypp 165.

Qian Y, Wu Z, Zhao R, Zhang L (2008). Vegetation patterns and speciesenvironment relationships in the Gurbantunggut Desert of China. Journal of Geographical Sciences 18(4):400-414.
Quézel P (1978). Analysis of the flora of Mediterranean and Saharan Africa. Annals of the Missouri Botanical Garden 479-534.

Ryan PJ, McKenzie NJ,Loughhead A, Ashton LJ (1996). New methods for forest soil surveys. In: Eldridge KG (Ed). Environ Manag: The Role of Eucalypts and Other Fast Growing Species. Proceedings of the Joint Australian-Japanese Workshop Held in Australia, 23rd-27th October. CSIRO Division of Forestry and Forest Products. CSIRO Publishing, Melbourne.

Salama FM, Abd El-Ghani MM,El-Tayeh NA, Amro AM, Abdrabbu HS (2017). Correlations between soil variables and weed communities in major crops of the desert reclaimed lands in southern Egypt. Rendiconti Lincei 28:363-378.

Shaheen AM(2002). Weed diversity of newly farmed lands on the southern border of Egypt (eastern and western shores of Lake Nasser). Pakistan Journal of Biological Science 5(7):802-806.

Täckholm V (1974). Students' flora of Egypt, $2^{\text {nd }}$ ed. Cairo University Press, Cairo, Egypt.

Tamado T, Milberg P (2000). Weed flora in arable fields of eastern Ethiopia with emphasis on the occurrence of Parthenium hysterophorus. Weed Research 40(6):507-521.

Ter Braak CJF (1990). Update notes: CANOCO version 3.1. Wageningen: Agricultural Mathematics Group.

Ter Braak CJF, Prentice IC (1988). A theory of gradient analysis. Advances in Ecological Research 18:271-317.

Vetaas OR, Salih EA,Jurasinski G (2012). Vegetation changes in the Red Sea Hills: from mist oasis to arid shrub. Plant Ecolology \& Diversity 5(4): 527-539.

Walkley A, Black IA (1934). An examination of the Degtjareff method for determining organic carbon in soils: Effect of variations in digestion conditions and of inorganic soil constituents. Soil Science 63:251-263.

Whittaker RH, Levin SA (1977). The role mosaic phenomena in natural communities. Theoretical Population Biology 12:117-139.

Williams CH, Twine ME (1960). Flame photometric method for sodium, potassium and calcium. In: Modern methods of plant analysis (Paech K and TraceyMV, editors.) Springer-Verlag, Berlin. Vol. 5 pp 535.

Woods JT, Mellon MA (1941). Chlorostannous-Molybdophosphoric blue colour method in sulfuric acid system. In soil chemical analysis by Jackson ML (1958). Prentice Hall International. Inc. London.

Yang H, Lu Q, Wu B, Zhang J, Lin Y (2006). Vegetation diversity and its application in sandy desert re vegetation on Tibetan Plateau. Journal of AridEnvironments 65:619-631. 